\title{
鉄吸収に関する研究（第7報） \\ Studies on Iron Absorption (Report 7)
}

食品及び食餌の質が血清鉄，血清鉄不飽和度，総血清鉄結合能に及洨す影響

The Effect of The Quality of Diet on Serum Iron, Unsaturate Iron Binding Capacity and Total Iron Binding Capacity

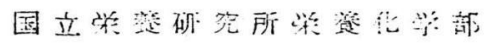

(Division of Chemistry of Nutrition, The National Institute of Nutrition)

$$
\text { 西原綾子 (Ayako Nishihara) }
$$

The higher serum iron value, lower unsaturate iron binding capacity level and better iron absorption were obtained from the animal protein diet than from vegetable protein one. It seems that it was caused by increasing the amino acids which stimulated the absorption of iron.

In case of the aged people vitamins had no effect on iron absorption, while Methyltestosterone played some role in upheaving serum iron level and in lowering unsaturate iron binding capacity level of the old men. But these were restored to the same levels as the adults within four months.

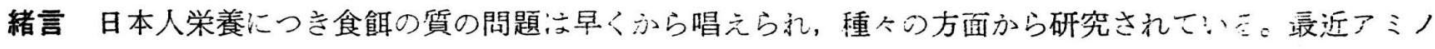
酸定量の進歩により，蛋白質の栄湌恃直らに乏礼構成しているアミノ酸の問題となり，各種食品中のアミノ

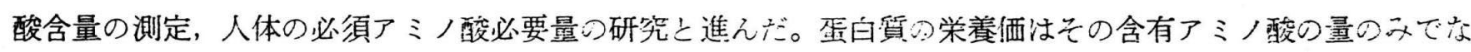
く, 質のみでもなく, それらの相互比率即亏, 人体了ミノ酸必要量の比率觉 provisional pattern として,

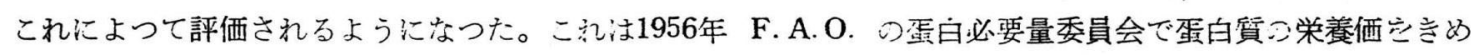
る方法としたものである。よつて蛋白質の栄養価の相異による鉄吸収の変動学検討した。

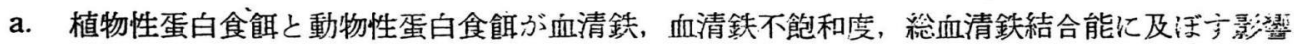
Litzel によると植物性食品, 卵黄, 肉等に含まれる鉄は一般: 二利用立え難いという。

人体においては 2 価鉄のみ利用されるので食品の鉄の還元性注鉄の吸収に重大である。Kirch 等は拿品の鉄 還元能力をみたのに，オレンジ汁 $77 \%$ ，トマト $98 \%$ ，牛肉 $31 \%$ ，卵白 $29 \%$ ，白パン $43 \%$ ，零鈴薯 $35 \%$ で あつたという。また蛋白質は消化酵素による分解で著しく還元性が高亲るというう。

著者は食飭を植物性蛋白のみとしたもの, 及びこれに動物性蛋白空加えたものとし, 蛋白質立卫ミ/酸組成 から評価して，关れが，血清鉄，血清鉄不飽和度，総血清鉄結合能:及ぼす影響をみた。

実験方法 被験者江健康成年男子 2 名定選えだ。

試験は植物蛋白食期と動物蛋白食期とし，各 2 日間ずつ行ない，2 日目を試験日とした。絪物蛋白食期に 壮-Lysine 1 日 $1.2 \mathrm{~g}$ を 3 回に分け，食事後に与えた。 
第 5 号

採血注午前10時, 午後 1 時, 10 時の 3 回, 何九も食前に行なつた。

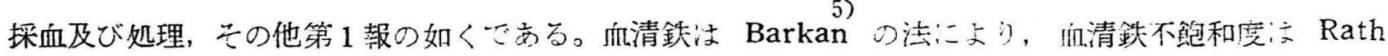
6)

Finch の法により定量した。

両試験期の献立注第 1 表, 第 2 表:こ示した。植物性蛋白食期:方蛋白 $58.3 \mathrm{~g}$, 熱量 $2539 \mathrm{Cal}$, 鉄量 $6.8 \mathrm{mg}$ 動物性蛋白食期江蛋白質 $72.6 \mathrm{~g}$ (動蛋比 $31.5 \%$ ), 熱量 $2843 \mathrm{Cal}$ ，泆量 $13.0 \mathrm{mg}$ でする。

第 1 表 植物性蛋白食毁就立

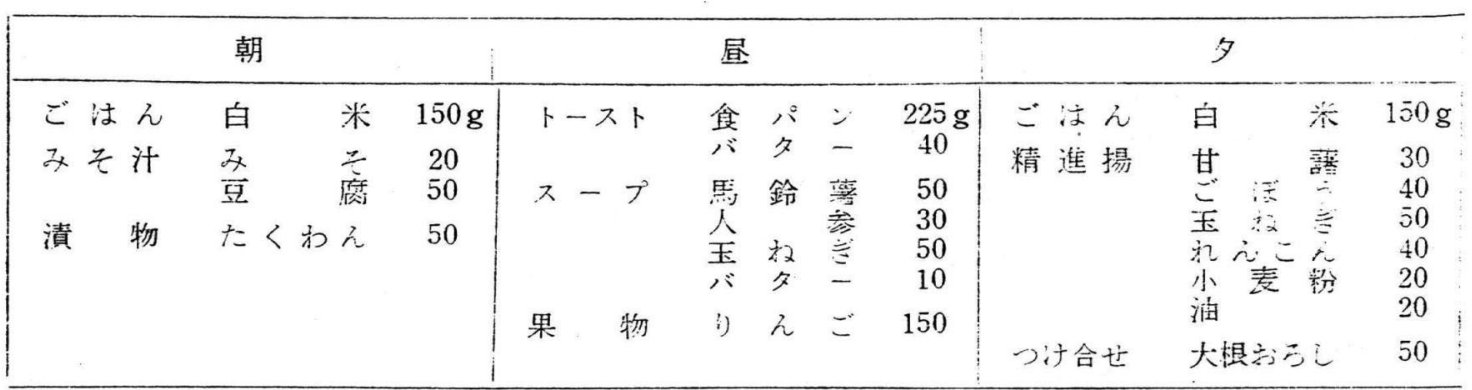

1 日栄養量=蛋白質 $58.3 \mathrm{~g}$, 熱量 $2539 \mathrm{Cal}$ ，铁量 $6.8 \mathrm{mg}$

第 2 表 動物性蛋白食䫀就立

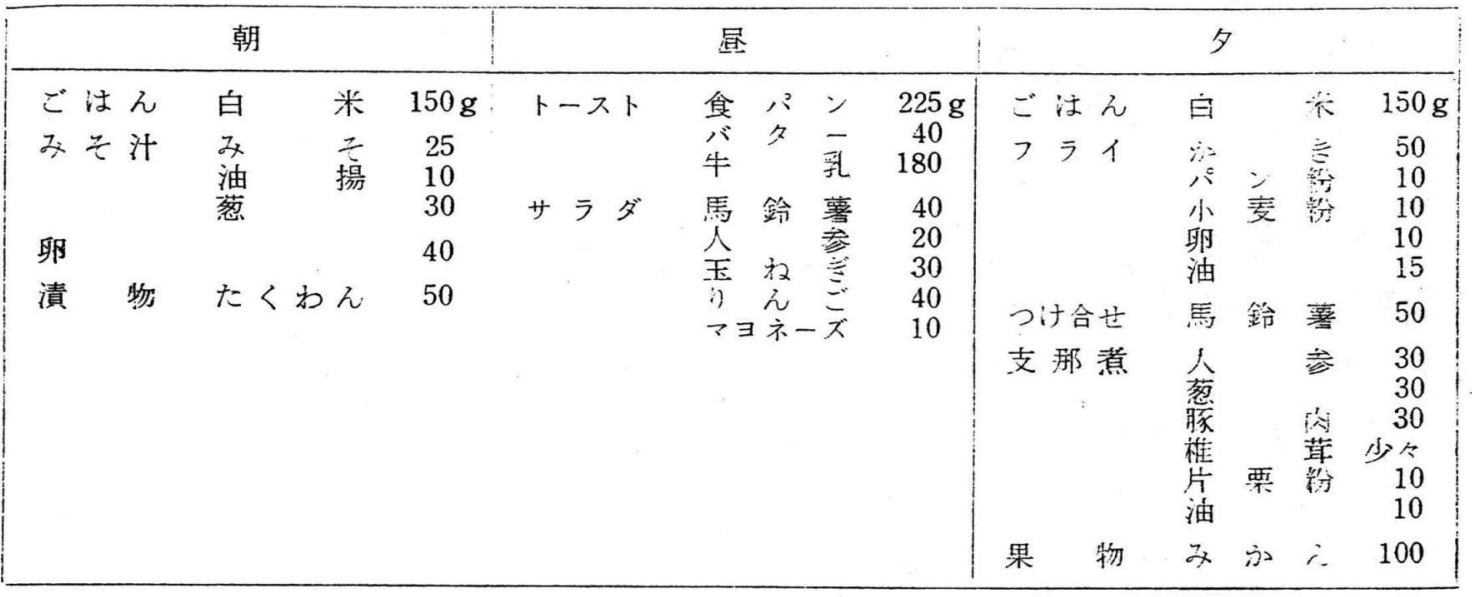

1 日栄養量=蛋白質 $72.6 \mathrm{~g}$ (動蛋比 $31.5 \%$ ), 熟量 $2843 \mathrm{Cal}$, 鉄量 $13.0 \mathrm{mg}$

第 3 表 必須了ミノ酸 1 日掑取量

\begin{tabular}{|c|c|c|c|c|c|c|c|c|c|c|}
\hline 試験期 & $\begin{array}{l}\text { ソロイ } \\
\text { シン }\end{array}$ & ロイシン & リジン & $\begin{array}{c}\text { メチオ } \\
\text { ン }\end{array}$ & シスチン & $\begin{array}{l}\text { 念硫了ミ } \\
\text { 酸 計 }\end{array}$ & $\begin{array}{l}\text { フェニル } \\
\text { アラニン }\end{array}$ & $\begin{array}{c}\text { スレオニ } \\
\text { ン }\end{array}$ & $\begin{array}{l}\text { トリプト } \\
\text { ファンン }\end{array}$ & バリン \\
\hline $\begin{array}{l}\text { 植物 性 } \\
\text { 㱏食 慨 }\end{array}$ & $2.32^{\mathrm{g}}$ & $3.90^{\mathrm{g}}$ & $1.83^{\mathrm{g}}$ & $0.77^{\mathrm{g}}$ & $0.85^{g}$ & $1.62^{\mathrm{g}}$ & $2.50^{\mathrm{g}}$ & $1.75^{\mathrm{g}}$ & $0.59^{g}$ & 2. $75^{\mathrm{g}}$ \\
\hline $\begin{array}{l}\text { アミノ酸基準 } \\
\text { 配合比に達せ } \\
\text { ぬもの }\end{array}$ & & & 79 & (63) & & 70 & & & $\pi i$ & \\
\hline 動 蛋 白食 性 & 3.77 & 5.84 & 3.54 & 1. 37 & 1.19 & 2. 56 & 3.54 & 2. 76 & 0.88 & 4.18 \\
\hline $\begin{array}{l}\text { アミノ酸基準 } \\
\text { 配合比に達せ } \\
\text { 以もの }\end{array}$ & & & & 79 & & (79) & & & 81 & \\
\hline
\end{tabular}

注（）注蛋白価 


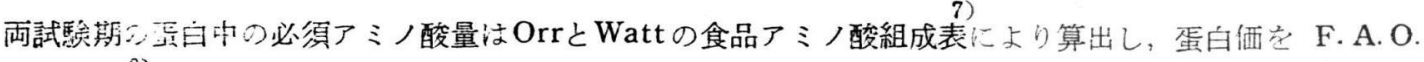
s)

の基準配合比つアミノ酸組成上比較し，第 3 表に示した。表に示す如く，植物性蛋白食期のアミ/酸で基準配

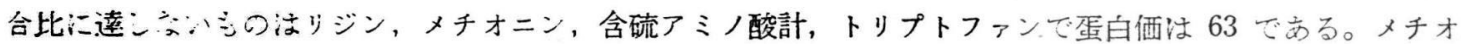
ニンが最低うつた。動物性蛋白食期で法基準配合比以下のものはメチォニン，含硫アミノ酸計，トリプトフ ァンー, 蛋白洒心 79 て含硫アミノ酸計が第 1 制限アミノ酸となつた。動物性蛋白食期ではリジンは十分とれ ていることになった。

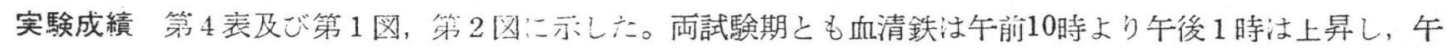

筷 4 表 食餉による血清鉄，血清鉄不飽和度，総血 清鉄結合能の変動

\begin{tabular}{|c|c|c|c|c|c|c|}
\hline \multirow{2}{*}{ 被 } & \multicolumn{3}{|c|}{ 植物性蛋白食餪期 } & \multicolumn{3}{|c|}{ 動物性蛋白食餌期 } \\
\hline & $\begin{array}{l}\text { 午前 } \\
10 \text { 時 }\end{array}$ & $\begin{array}{l}\text { 午後 } \\
1 \text { 時 }\end{array}$ & 10 時 & $\begin{array}{l}\text { 午前 } \\
10 \text { 時 }\end{array}$ & $\begin{array}{l}\text { 午後 } \\
1 \text { 時 }\end{array}$ & 10 時 \\
\hline $\begin{array}{l}\text { S. I. } \\
\text { U. I B B C. } \\
\text { T. I B B. C. }\end{array}$ & $\begin{array}{c}\gamma \% \\
128 \\
148 \\
276\end{array}$ & $\begin{array}{c}\gamma \% \\
149 \\
119 \\
268\end{array}$ & $\begin{array}{c}\gamma \% \\
77 \\
199 \\
276\end{array}$ & $\begin{array}{c}\gamma \% \\
147 \\
130 \\
277\end{array}$ & $\begin{array}{c}\gamma \% \\
158 \\
120 \\
278\end{array}$ & $\begin{array}{r}\gamma \% \\
68 \\
194 \\
262\end{array}$ \\
\hline $\begin{array}{ll} & \text { S.I } \\
\text { H.M. } & \text { U.I.B.C. } \\
& \text { T.I.B.C. }\end{array}$ & $\begin{array}{l}124 \\
180 \\
304\end{array}$ & $\begin{array}{l}132 \\
156 \\
288\end{array}$ & $\begin{array}{r}75 \\
200 \\
275\end{array}$ & $\begin{array}{l}127 \\
170 \\
297\end{array}$ & $\begin{array}{l}152 \\
118 \\
270\end{array}$ & $\begin{array}{r}77 \\
214 \\
291\end{array}$ \\
\hline
\end{tabular}

注 S.I. = 盤清鉄

U.I.B.心.=血清鉄不飽和度

T. I . B . C . = 総血清鉄結合能

第1図食饃の差異による血清鉄, 血清鉄 不飽和度，総血清鉄結合能の変動

— 血清鉄

……血清鉄不飽和度

- - 総血清鉄結合能

Subj. N. M.

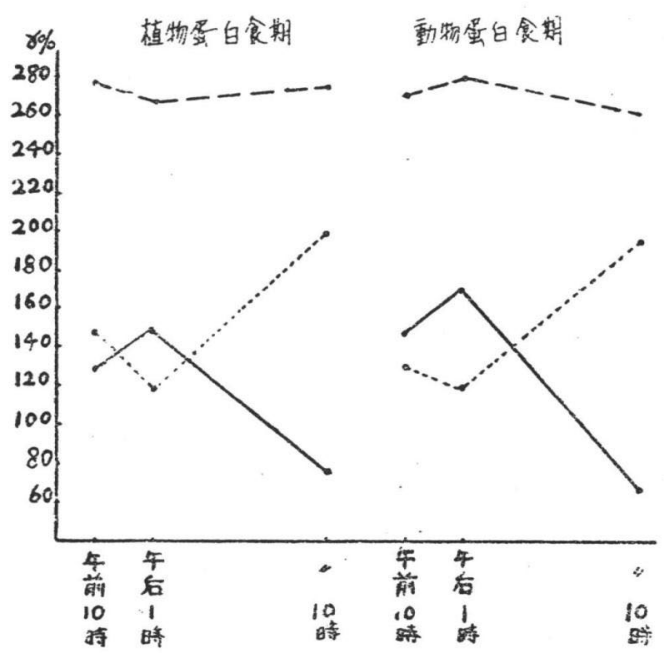

後10時は甚だしく低下し，血清鉄不飽 和度は血清鉄と逆の方向它示し, 総血 清鉄結合能は変動少く, 正常時の日内 変動をあらわしていた。植物性蛋白食 期之動物性蛋白食期を比較すると血清 鉄量は動物性蛋白食期の午前10時亡午 後 1 時注稙物性蛋白食期よりも明らか に高かつた。午後10時の夜間における 低下注両期同程度であつた。血清鉄不 飽和度は血清鉄の上昇に逆に低く，夜 間は両期とも同程度の上昇であつた。 総血清鉄結合能は両期において差をみ

第 2 図 食餌の差異による血清鉄, 血清鉄 不飽和度, 総血清鉄結合能の変動

— 血清鉄

… 血清鉄不飽和度

- - 総血清鉄結合能

Subj. H. M.

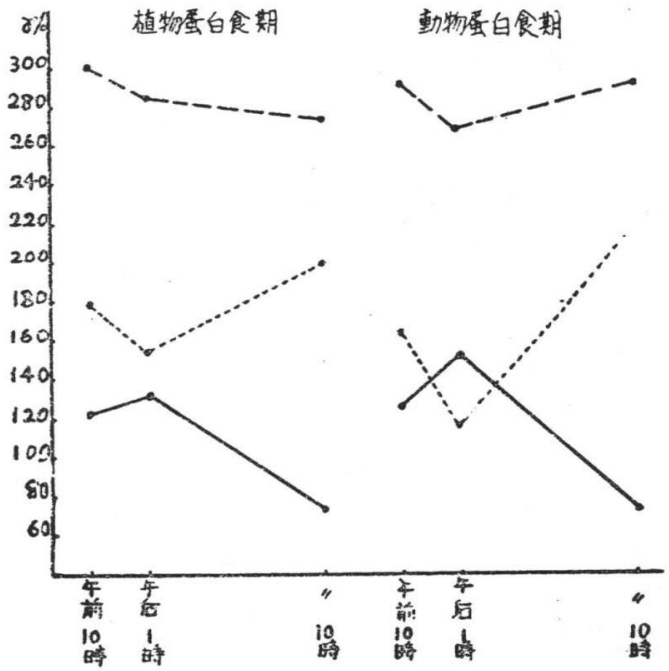

とかたい。動物性蛋白食期が血清鉄の日中の上昇が高く，鉄吸収の多いのが認められた。 
b. ビタミン類，ホルモン投与が老年者の血清鉄，血清泆不飽和度，総血清鉄結合能に及ぼす影響

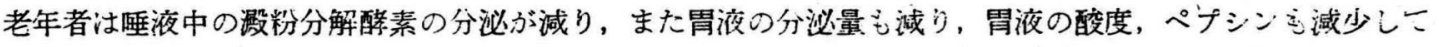

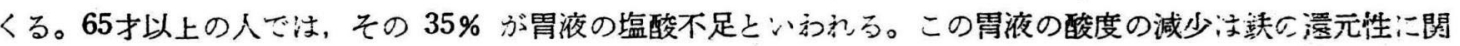

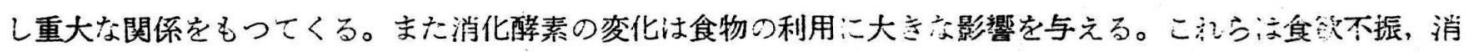

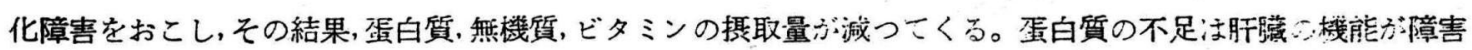

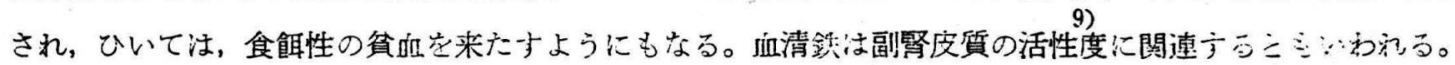

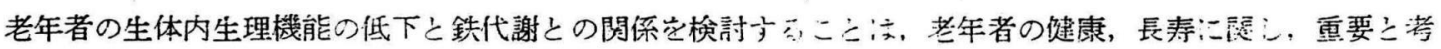
えられる。

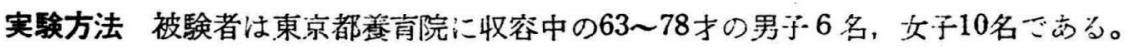

試験は対照期と負荷期汇分汁た。負荷したのは男性ホルモンシしてェナルモン 1 日 $15 \mathrm{mg}$ ，ごそミン A 1000 I. U., カロチン 1500 I.U., B $100 \mathrm{mg}, B_{2} 100 \mathrm{mg}, B_{6} 1 \mathrm{mg}, C 100 \mathrm{mg}$ 及びョーグルト 300cc で, 夫ヶ単独に各負荷群に与えた，4 力月間継続した。その間，毎月 1 回宛試駼学行ない，その成績を比較した。

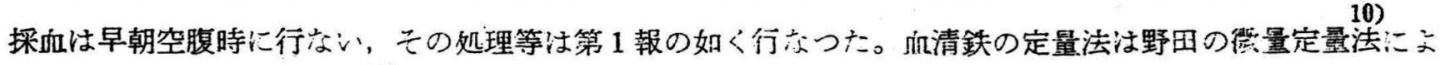
り，血清鉄不飽和度は野田の法によつた。

第 5 表 ビタミン類，ホルモン投与が老年者の血清鉄，血清鉄不飽和度，総血清鉄結合能に攴洼け影響

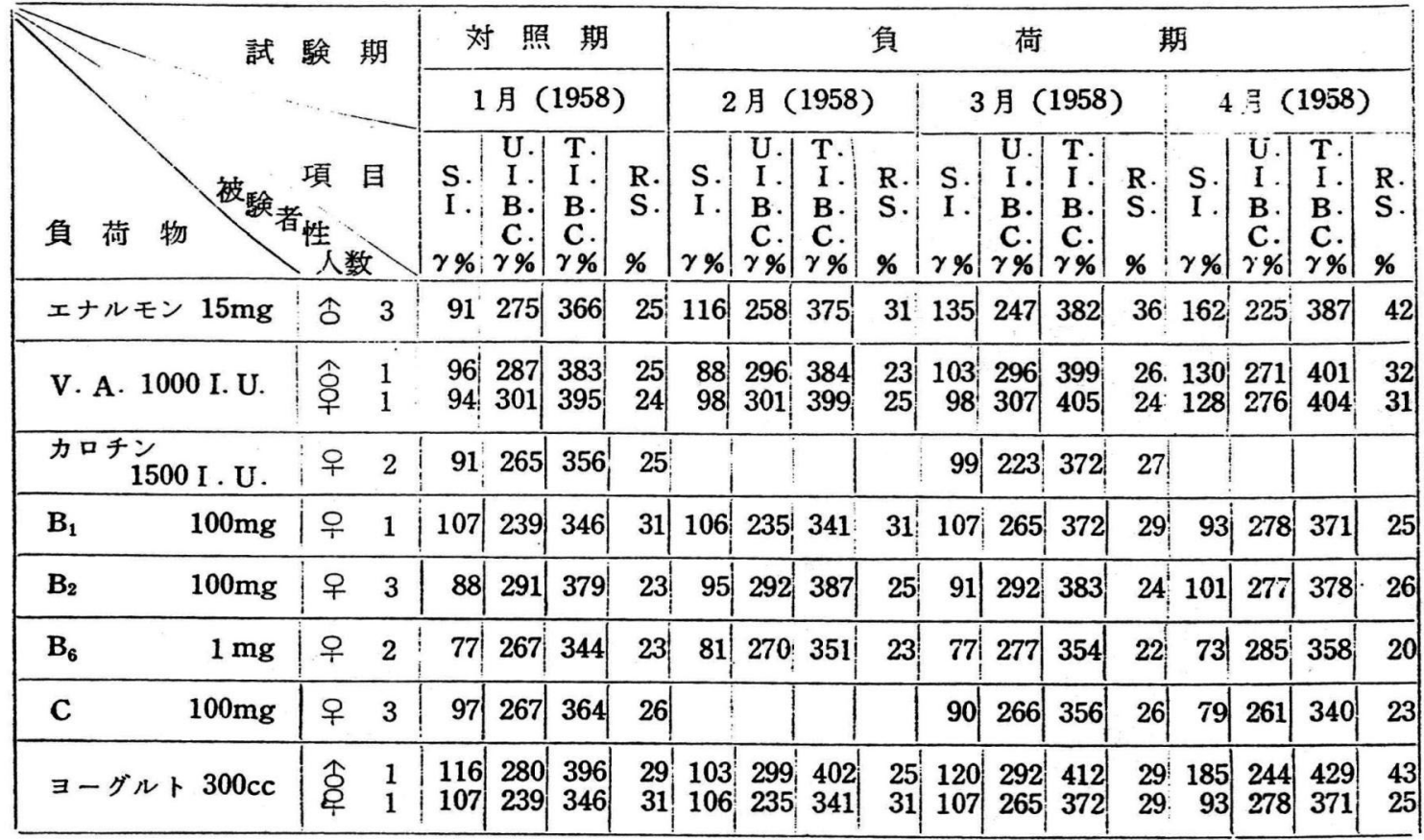

注 S. I. =血清鉄, U. I. B.C. =血清鉄不飽和度, T. I. B. C. =総血鉄清鉄結合能， R.S. =飽和率

実駼成䥊 第 5 表に示した如くである。ビタミン $A$ ，カロチン， $B_{1}, B_{2}, B_{6}, C$ の各負荷群については，

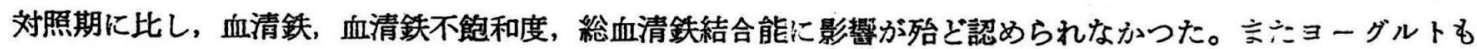
影響がなかつた。エナルモンを投与した男子は投与後 1 カ月で既に血清鉄は上㫒し，血清鉄不飽和度泣低下し 次第に血清鉄は增加し，4 カ月後には成年男子と大差を認めないようになつた。

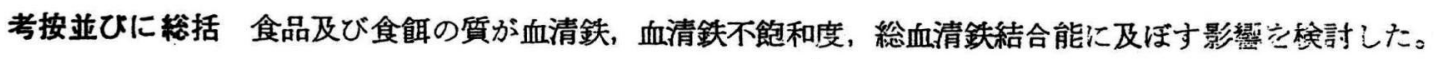




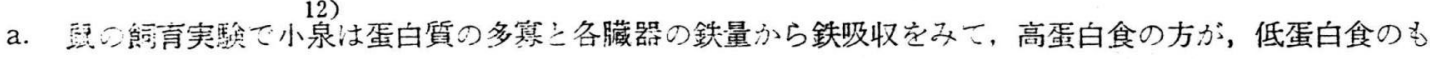
のミう総铁量ぶ大であつたという。

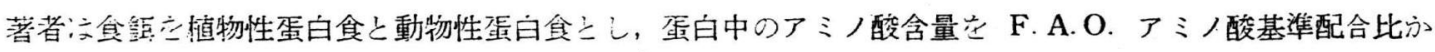

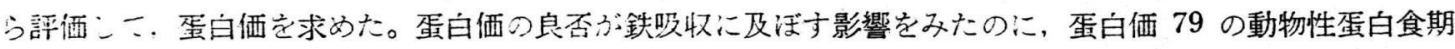
の方念，蛋白洒 63 の植物性蛋白食期より ，血清鉄が高く，鉄の吸収のよいのをみ上めた。

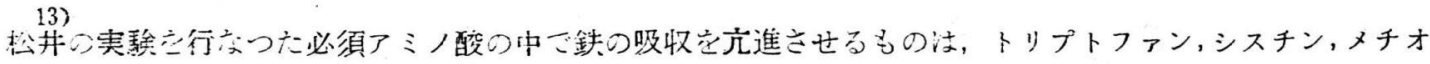

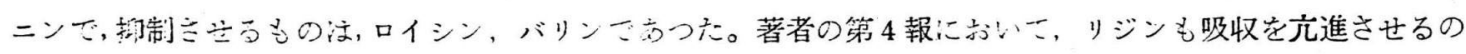

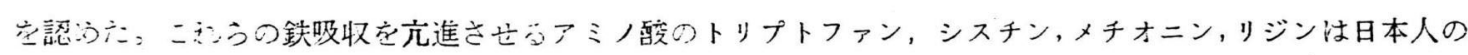

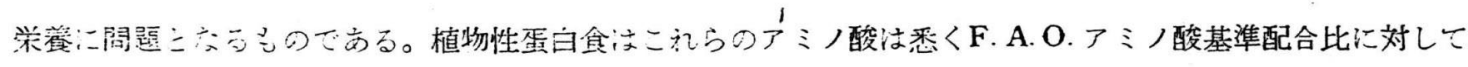
劣り,メチォニン方第 1 制限アミノ酸ご, 蛋白洒: 63 であつた。動物性蛋白食ではりジンは基準配合比以上

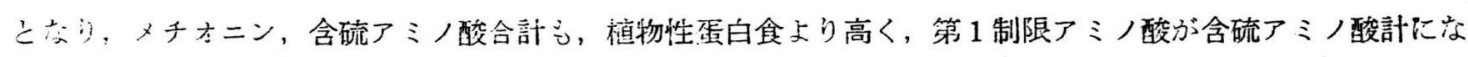

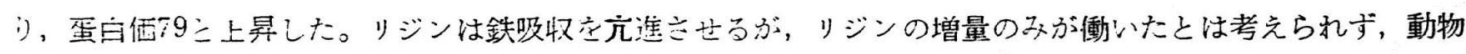

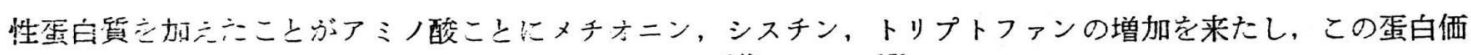

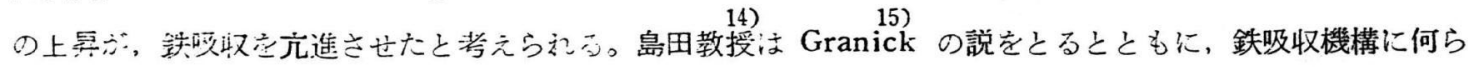

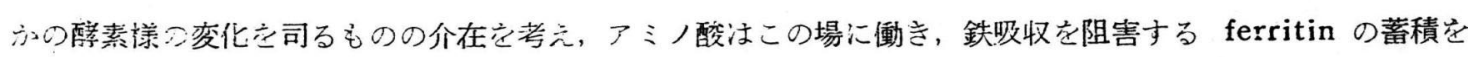

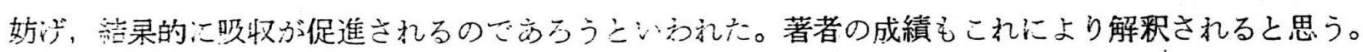

b. Klein : 盰贜上鉄代謝は密接な関係があると述べ，尼子の浴風園の老年者の調查では老年者は多少なり

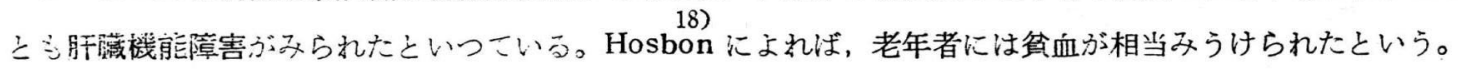
老年者方成年者に比し，血清鉄が低々血清鉄不飽和度が高いことは第 5 報: こ述べたが，明らが鉄欠乏性盆血

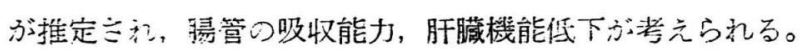

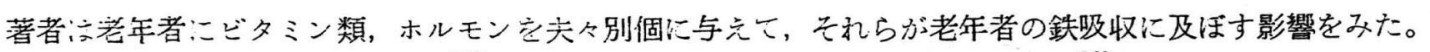
ビタミン渿之銑吸収に関してはV.B.

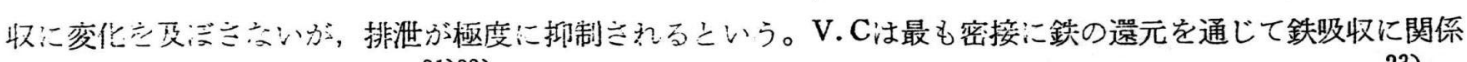

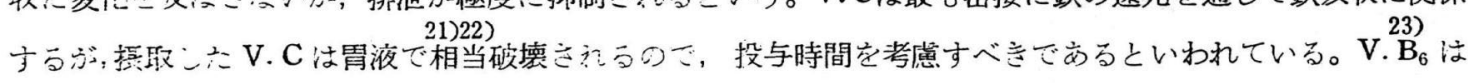

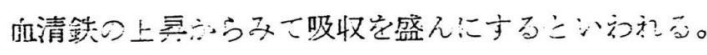

著者の坄与ンたビタミン $\mathrm{A}$ ，カロチン， $\mathrm{B}_{1} ， \mathrm{~B}_{2}, \mathrm{~B}_{6} \mathrm{C}$ ，何れも鉄吸収に影響はないようであつた。V.C は 投与時間さ琵係さ考えられ，食事と共汒与六亡ニ之が胃液の分泌の盛んな時に当り，或いは破壊されたのかも しれ琼い。ヨーグルトも影響はは泓つた。

男惟ホルニンの欠乏が貧血を招来するう，Blacher，Steinglass により報告された。また男性ホルモン投与 こニり正常動物つ赤血球数を増加させ，男性ホルモン久乏によつて生じた貧血を一部回復させることが Craft

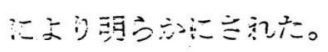

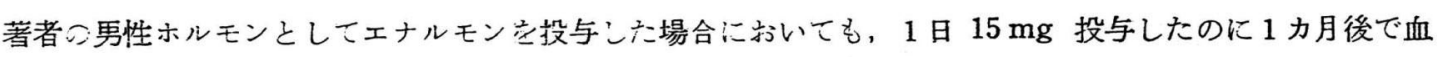
清鉄泫上景し，血清鉄不飽和度は下降し，飽和率は $25 \%$ から $31 \%$ と上昇した。 4 力月後には成年男子の域

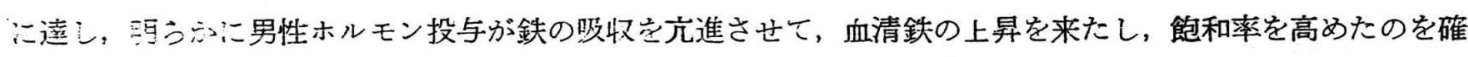
的心

結論 䓹慨の質を動物性蛋白食と植物性蛋白食にした際の血清鉄, 血清鉄不飽和度，総血清鉄結合能に及ほ

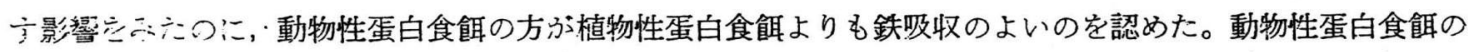




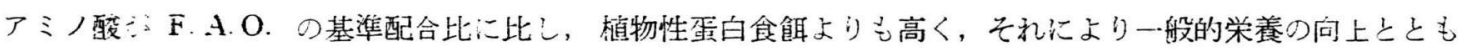

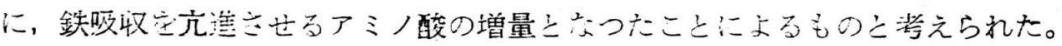

また，身体諸器官の機能低下せる老年者の鉄吸収は，ビタミン投与では影響は認められなかつたが，男性ホ ルモン投与の男子法投与後 1 力月より血清鉄の上昇夌み上る，飽和率汶上昇し，4 力月後法，成年男子之同程 度宗で回復した。男性ホルモン投与が明ら动に老年者の鉄吸収に良い影響を与えたのをみとめた。

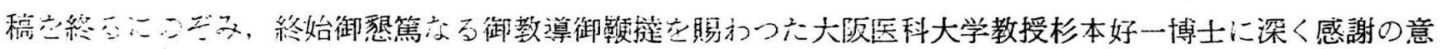

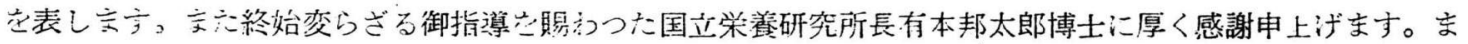
た終始変らさこ御愁篤なる御指導並びこ御校閲堂睗わつた国立栄養研究所栄養化学部長田村盈之輔博士並びに

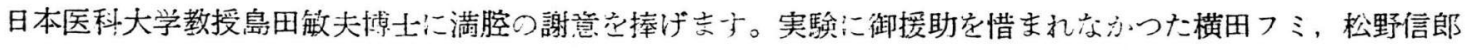
両氏汇厚?感謝放し安少。

文献

1) Lintzel, W. : Z. Biol., 83, 289 (1925)

2) Kirch, E. R., et al. : J. Biol. Chem., 171, 687 (1947)

3 ) Belgium, O., et al. : J. Biol. Chem., 177, 531 (1949)

4 ）小泉：日十生化学会総会発表 (1955)

5) Barkan. G., Walker, B. S. : J. Biol. Chem., 135, 37 (1940)

6) Rath, C. E., Finch, C. A. : J. Clin. Invest., 28, 79 (1949)

7) Orr, M. L., Watt, B. K. : Amino acid content of foods (1957)

8 ）科学技街宁資源局：F. A. O. 蛋白所要量 (1958)

9 ) Braunsteiner, H. et al. : Klin. Wschr., 30, 394 (1952)

10) 影田：生化学, 29, 199 (1957) 11) 野田：生化学, 30, 304 (1958)

12）小京：栄意食糧学会総会発表（1954） 13）松井：日医大誌，20，524，618 (1953)

14) 島田：綜合医学，10，112 (1953)

15) Granick, S., et al. : J. Biol. Chem., 164, 737 (1946)

16) Klein, E., et al. : Klin. Wschr., 34, 297 (1956)

17) 尼于：日本医学会総会講演 (1951)

18) Hobson W. : Geriatrics, 8, 251 (1953)

19) Lemberg. R. : Hematin compound and Bili pigment:567, Inter Science Publishers. New York (1949); 島田 : 日医大誌, 19, 849 (1952)

20) Lattanzi, A., et al. : Boll. soc. ital. biol. sper. 24, 559 (1948) cit. Chem. Abst.; 鳥田 : 日医大誌，19，849 (1952)

21) Braum, H. et a1. : Klin. Wschr., 27, 468 (1949)

22) 吉野：生化学, 27 (8) 529 (1955)

23) Lamberg, R. : Hematin compound and Bili pigment:567, Inter Science Publishers. New York (1949); 島田：日医大誌，19，850 (1952)

24) Blacher, C. : Biol. Generalis, 2, 435 (1926)

25) Steinglass, P. : Proc. Soc. Exp. Biol. \& Med., 48, 169 (1941)

26) Craft, W. : Endocrinol, 29, 596 (1941) 